\title{
Novel Insights into Tat Pathway in Xanthomonas oryzae pv. oryzae Stress Adaption and Virulence: Identification and Characterization of Tat-Dependent Translocation Proteins
}

\author{
Guichun Wu, Panpan Su, Bo Wang, Yuqiang Zhang, Guoliang Qian, ${ }^{\dagger}$ and Fengquan Liu ${ }^{\dagger}$
}

\begin{abstract}
All authors: Department of Plant Pathology, College of Plant Protection, Nanjing Agricultural University, Nanjing 210095, China/Key Laboratory of Integrated Management of Crop Diseases and Pests (Nanjing Agricultural University), Ministry of Education, P.R. China; and sixth author: Institute of Plant Protection, Jiangsu Academy of Agricultural Sciences, Nanjing 210014, P.R. China.
\end{abstract}

Accepted for publication 22 May 2017.

\begin{abstract}
Xanthomonas oryzae pv. oryzae, an economically important bacterium, causes a serious disease in rice production worldwide called bacterial leaf blight. How X. oryzae pv. oryzae infects rice and causes symptoms remains incompletely understood. Our earlier works demonstrated that the twinarginine translocation (Tat) pathway plays an vital role in X. oryzae pv. oryzae fitness and virulence but the underlying mechanism is unknown. In this study, we used strain PXO99A as a working model, and identified 15 potential Tatdependent translocation proteins (TDTP) by using comparative proteomics and bioinformatics analyses. Combining systematic mutagenesis, phenotypic characterization, and gene expression, we found that multiple TDTP play key

roles in $X$. oryzae pv. oryzae adaption or virulence. In particular, four TDTP (PXO_02203, PXO_03477, PXO_02523, and PXO_02951) were involved in virulence, three TDTP (PXO_02203, PXO_03477, and PXO_02523) contributed to colonization in planta, one TDTP (PXO_02671) had a key role in attachment to leaf surface, four TDTP (PXO_02523, PXO_02951, PXO_03132, and PXO_03841) were involved in tolerance to multiple stresses, and two TDTP (PXO_02523 and PXO_02671) were required for full swarming motility. These findings suggest that multiple TDTP may have differential contributions to involvement of the Tat pathway in $X$. oryzae $\mathrm{pv}$. oryzae adaption, physiology, and pathogenicity.
\end{abstract}

Xanthomonas is an important genus of gram-negative bacteria that infects hundreds of economically important crops worldwide (Rodriguez-R et al. 2012; Royer et al. 2013). X. oryzae pv. oryzae causes one of the most serious diseases in rice, known as bacterial leaf blight, in many rice-growing areas (Chatterjee and Sonti 2002; Lee et al. 2005). A variety of virulence determinants, including adhesins, extracellular polysaccharides (EPS), cell motility, and stress tolerance, have been shown to play critical roles in promoting $X$. oryzae pv. oryzae infection (Büttner and Bonas 2010; Niño-Liu et al. 2006; Salzberg et al. 2008). Expression of these virulence determinants is differentially controlled by multiple regulatory pathways, including two-component signal transduction systems (Büttner and Bonas 2010), the cyclic di-GMP signaling system (Ham 2013), the quorum sensing system (Ham 2013), the interkingdom signaling system (González et al. 2013), and transcriptional regulators such as GamR (Rashid et al. 2016), Clp (Jeong et al. 2008), and KdgR (Lu et al. 2011).

Protein secretion systems have also been shown to promote bacterial infection during the interactions between $X$. oryzae pv. oryzae and rice (Büttner and Bonas 2010). In particular, the $X$. oryzae pv. oryzae type II, type III, and type V secretion systems are most extensively studied. Cell-wall-degrading enzymes such as lipase/esterase (LipA), xylanase, and cellulase are secreted through the type II secretion system (T2SS) and have been demonstrated to contribute to the promotion of $X$. oryzae pv. oryzae infection and virulence (Aparna et al. 2009; Büttner and Bonas 2010; Jha et al. 2007). The type III secretion system of $X$. oryzae pv. oryzae primarily

†Corresponding authors: G. Qian; E-mail: glqian@njau.edu.cn, and F. Liu; E-mail: fqliu20011@sina.com

*The $\boldsymbol{e}$-Xtra logo stands for "electronic extra" and indicates that six supplementary figures and four supplementary tables are published online.

(c) 2017 The American Phytopathological Society serves to deliver effector proteins such as AvrXa27, PthXo6, and PthXo7 that are required for bacterial full virulence and modification of host immune defenses (Block et al. 2008). The $X$. oryzae pv. oryzae adhesins such as XadA are type V secretion system (T5SS)-secreted proteins that function in bacterial attachment to the leaf surface and colonization in xylem vessels (Das et al. 2009). In addition, our earlier works show that the twin-arginine translocation (Tat) pathway, which is involved in the translocation of secretory proteins across the cytoplasmic membrane, is required for $X$. oryzae pv. oryzae virulence (Chen et al. 2009); however, the underlying mechanism (i.e., what are the Tat-dependent translocation proteins [TDTP] and their functions) remain to be elucidated in X. oryzae pv. oryzae.

In most gram-negative bacteria, the Tat pathway consists of a key component protein with six transmembrane helixes, called TatC, and two structurally related TatA family proteins with a single transmembrane helix, called TatA and TatB (Patel et al. 2014). Substrate proteins that are translocated by the Tat pathway usually possess highly conserved twin-arginine (S/T-R-R-X-F-L-K) motifs in their N-terminal signal peptides (Kudva et al. 2013; Patel et al. 2014). Proteins that are translocated by the main secretion (Sec) pathway are usually in an unfolded state (Kudva et al. 2013). However, before Tat substrates are translocated into the periplasm, they are completely folded in the cytoplasm and most of them bind to function-related cofactors such as molybdopterin, FeS, and $\mathrm{NiFe}$ centers (Ochsner et al. 2002). The indispensable roles of the Tat pathway in pleiotropic phenotypes and the virulence of various pathogens have been investigated in several studies(Bronstein et al. 2005; González et al. 2007; Pradel et al. 2003; Rodríguez-Sanz et al. 2010). In many cases, it is considered challenging to link the pleiotropic phenotypes of the Tat pathway to particular Tat substrate proteins (De Buck et al. 2008). Nevertheless, with the development of proteomic studies (Hitchcock et al. 2010; Joshi et al. 2010) and bioinformatics prediction programs (Bagos et al. 2010; Bendtsen et al. 2005; Rose et al. 2002), an increasing number of previously 
uncharacterized proteins are currently identified as Tat substrates or TDTP. Most of these proteins play crucial roles in various physiological and biological processes, including iron acquisition and detoxification, electron transport and oxidationreduction, and the biogenesis of the cell envelope and pathogenicity, in several human- and plant-pathogenic bacteria (Ball et al. 2016; González et al. 2007; Hitchcock et al. 2010;). For example, the phospholipases $\mathrm{PlcH}$ and $\mathrm{PlcN}$ secreted by the Tat pathway degrade host cellular lipids and contribute to the virulence in Pseudomonas aeruginosa (Ochsner et al. 2002). The $\beta$-lactamase BRO-2 has been demonstrated to be Tat dependent and to play a key role in virulence by protecting the peptidoglycan cell wall of Moraxella catarrhalis from damage caused by $\beta$-lactam antibiotics (Balder et al. 2013). In Escherichia coli, defects in the cell envelope can be observed in Tat-disrupted mutant strains because the incorrect export of the Tat substrates AmiA and AmiC affects the integrity of the bacterial outer membrane (Ize et al. 2003).

To the best of our knowledge, the TDTP in X. oryzae pv. oryzae and their functions are still unknown. Investigating this point will facilitate understanding whether the Tat pathway controls $X$. oryzae pv. oryzae stress adaption and virulence via its dependent translocation proteins. In the present work, we applied both comparative proteomics and bioinformatics analyses to discover the potential TDTP in X. oryzae pv. oryzae. This led to identification of 15 candidate TDTP. Combining multiple genetic and phenotypic approaches, we dissected the role of each tested TDTP in X. oryzae pv. oryzae virulence, growth, colonization, and adaption to multiple stress. This not only identifies new $X$. oryzae pv. oryzae virulence determinants but also establishes a previously uncharacterized connection between regulatory effect of the Tat pathway and its dependent translocation proteins in X. oryzae pv. oryzae. The latter point also helps to strengthen our understanding of how the Tat pathway controls $X$. oryzae pv. oryzae physiology, stress adaption, and virulence.

\section{MATERIALS AND METHODS}

Bacterial strains, plasmids, and culture conditions. The details regarding the bacterial strains and plasmids used in this work are provided in Supplementary Table S1. The wild-type (WT) strain PXO99A of X. oryzae pv. oryzae and its derivatives were cultured at $28^{\circ} \mathrm{C}$ in liquid nutrient broth (NB) (beef extract, $3 \mathrm{~g} /$ liter; yeast extract, $1 \mathrm{~g} /$ liter; poly-peptone, $5 \mathrm{~g} /$ liter; and sucrose, $10 \mathrm{~g} /$ liter) or NB agar (NA) plates. E. coli DH5 $\alpha$ used for plasmid constructions was grown at $37^{\circ} \mathrm{C}$ in Luria-Bertani (LB) broth or LB agar plates. When required, the media were supplemented with antibiotics at the following concentrations for E. coli and X. oryzae pv. oryzae: ampicillin at $100 \mu \mathrm{g} / \mathrm{ml}$, kanamycin $(\mathrm{Km})$ at $50 \mu \mathrm{g} / \mathrm{ml}$, and gentamicin at $5 \mu \mathrm{g} / \mathrm{ml}$.

Bioinformatics analyses. The sequence information was obtained from the PXO99A genome database (GenBank accession NC_010717.2) (Salzberg et al. 2008). Predictions of protein subcellular localization were performed with PSORTb v3.0 (Yu et al. 2010) and CELLO v2.5 (Yu et al. 2006). To predict potential Tat substrates, 4,375 protein sequences in strain PXO99A were analyzed using the following three major Tat prediction programs: PRED-TAT (Bagos et al. 2010), TatP v1.0 (Bendtsen et al. 2005), and TATFIND v1.4 (Rose et al. 2002). The putative signal peptide cleavage sites, which are normally located downstream from the Tat motif, for the predicted Tat substrates were identified using SignalP v4.0 (Petersen et al. 2011). In the present study, if a protein contains a putative signal peptide cleavage site, which is predicted to be located upstream from the Tat motif, then this protein is defined as a controversial Tat substrate for easy understanding. Cluster of orthologous groups analyses were performed using eggNOG v4.5 (Huerta-Cepas et al. 2016) and Protein Basic Local Alignment Search Tool (BLAST) (Mount 2007). Computation of the theoretical protein isoelectric point and molecular weight for selected proteins was performed using the ExPASy tool (Artimo et al. 2012).

Preparation of $X$. oryzae pv. oryzae extracellular proteins. Extracellular samples for comparative proteome analysis were prepared as described previously, with minor modifications (Qian et al. 2013b). Briefly, the WT PXO99A and the tatC in-frame deletion mutant $(\triangle t a t C)$ were cultured in $250 \mathrm{ml}$ of $\mathrm{NB}$ medium at $28^{\circ} \mathrm{C}$ to the midexponential phase (optical density at $600 \mathrm{~nm}\left[\mathrm{OD}_{600}\right]=3.0$ ) (Supplementary Fig. $\mathrm{S} 1$ ). Then, $0.25 \mathrm{ml}$ of bacterial protease inhibitor cocktail purchased from Sigma-Aldrich was added into each bacterial culture. Bacterial cells were removed via centrifugation $\left(6,000 \times g\right.$ at $4^{\circ} \mathrm{C}$ for $\left.30 \mathrm{~min}\right)$, and the supernatant was filtered through $0.22-\mu \mathrm{m}$ filter membranes. The cellfree supernatant was frozen at $-80^{\circ} \mathrm{C}$ and lyophilized to complete dryness. This dryness was dissolved in double-diluted $\mathrm{H}_{2} \mathrm{O}$ and purified using a protein Clean-up Kit (GE Healthcare Life Sciences). Isoelectric focusing buffer containing $7 \mathrm{M}$ urea, $2 \mathrm{M}$ thiourea, 4\% 3-[(3cholamidopropyl)dimethylammonio]-1-propanesulfonate (CHAPS), $40 \mathrm{mM}$ dithiothreitol, and $2 \%$ ( $\mathrm{vol} / \mathrm{vol})$ immobilized $\mathrm{pH}$ gradient buffer ( $\mathrm{pH} 4$ to 7 ) was used to dissolve the pellet. The concentration of each protein was determined using the QuickStart Bradford Protein Assay Kit (Bio-Rad Laboratories) according to the manufacturer's instructions. The resulting protein was then stored at $-80^{\circ} \mathrm{C}$ for later use in two-dimensional gel electrophoresis (2-DE). Three biological experiments were conducted for the comparative proteomics in this study.

2-DE and matrix-assisted laser desorption/ionization time-of-flight mass spectrometry analysis. The methods used for 2-DE and matrix-assisted laser desorption/ionization time-offlight mass spectrometry (MALDI-TOF-MS) analysis were applied according to our earlier works (Qian et al. 2013b; Zhao et al. 2011). The protein samples were adjusted to the appropriate loading amount $(200 \mu \mathrm{g})$ and separated via 2-DE. Silver staining was performed according to a published procedure (Zhao et al. 2011). The comparative analysis of the resulting images was performed using the PDQuest v7.2 software (Bio-Rad Laboratories). The spots of differentially secreted proteins were excised manually from the 2-D gels. Destaining of silver-stained gels and in-gel trypsin digestion were performed as previously described (Calhoun et al. 2010). The masses of tryptic-digested peptide were determined using a MALDI-TOF-TOF 4700 mass spectrometer (Applied Biosystems). The resulting data were analyzed using the Data Explorer software package (Applied Biosystems), and the identification was performed with the MASCOT program (Matrix Science) using the probability-based Mowse score and a threshold of $P<0.05$. Similarity searches were performed using the BLAST and the genome database of strain PXO99A (Salzberg et al. 2008).

Genetic methods. To generate in-frame deletion mutants of a target gene, WT PXO99A was used as a parental strain and allelic homologous recombination was applied using the suicide vector pK18mobsacB, as described previously (Qian et al. 2013a). Briefly, two flanking regions of the target gene were amplified with specific primer sets (Supplementary Table S2). The two polymerase chain reaction $(\mathrm{PCR})$ fragments were digested with the corresponding restriction enzymes and ligated into $\mathrm{pK} 18$ mobsacB. The resulting recombinant vectors for each target gene were validated by sequencing and introduced into WT PXO99A via electroporation. Transformants were selected on NA plates without sucrose containing $\mathrm{Km}$ at $50 \mu \mathrm{g} / \mathrm{ml}$ for the first crossover event. Positive colonies were then plated on NA plates containing 10\% (wt/vol) sucrose to screen for a second crossover event. After two rounds of recombination, the resulting in-frame deletion mutants were confirmed by PCR analysis (Supplementary Table S3). For complementation, each target gene with its predicted promoter region was amplified by PCR using the designated primers and cloned into the broad-host-range vector pUFR034 (DeFeyter et al. 1990) or pUFR047 (Andrade et al. 2014). The resulting plasmid was then transferred into the corresponding mutant via electroporation to generate the complemented strains. 
Pathogenicity assay. Pathogenicity assays were performed on susceptible 'IR24' rice using the standard leaf-clipping method, as previously described (Yang and Bogdanove 2013). All rice plants were maintained in a greenhouse at $28^{\circ} \mathrm{C}$ with approximately $70 \%$ relative humidity. The $X$. oryzae pv. oryzae strains were grown in $\mathrm{NB}$ medium at $28^{\circ} \mathrm{C}$. All tested strains were adjusted to a concentration of $\mathrm{OD}_{600}=0.5$ using a BioPhotomer (Eppendorf). Inoculations were performed by immersing scissors in freshly prepared bacterial suspensions and clipping approximately $2 \mathrm{~cm}$ from the tips of fully expanded leaves of 5- to 6-week-old rice plants. The lesion lengths (length of grayish symptoms from the inoculated tip to the leading edge) were measured 8 and 16 days postinoculation (dpi), and representative images of IR24 leaves were photographed at the indicated times. At least 10 leaves were inoculated with each tested strain in each replicate. The biological experiments were performed three times.

Growth assay. The growth dynamics of $X$. oryzae pv. oryzae strains in susceptible IR24 rice were determined using previously described methods (Yang and Bogdanove 2013), with minor modifications. Leaves of 5- to 6-week-old rice plants in the greenhouse were inoculated with the tested strains at a concentration of $\mathrm{OD}_{600}=0.5$ using the leaf-clipping method described above. Samples of inoculated leaves were collected every 8 days $(0,8$, and $16 \mathrm{dpi})$, followed by surface sterilization in $70 \%$ ethanol for $1 \mathrm{~min}$ and $0.5 \%$ ( $\mathrm{vol} / \mathrm{vol}$ ) sodium hypochlorite solution for $1 \mathrm{~min}$. The leaf samples were washed twice with sterile water for $5 \mathrm{~s}$. The leaf samples were then sliced into small pieces and homogenized in sterile water using sterilized mortars and pestles. The resulting homogenates were diluted serially and plated in triplicate on NA plates supplemented with the appropriate antibiotics. After incubation at $28^{\circ} \mathrm{C}$ for 3 to 4 days, the CFU on each plate were estimated for each tested strain and converted into the $1 \mathrm{~g}$ of CFU per leaf for further data analysis.

To determine bacterial growth in nutrient medium, $X$. oryzae $\mathrm{pv}$. oryzae strains were grown in $\mathrm{NB}$ medium at $28^{\circ} \mathrm{C}$, pelleted by centrifugation at $6,000 \times g$ for $5 \mathrm{~min}$, and resuspended in sterilized distilled water to a concentration of $\mathrm{OD}_{600}=1.0$. Then, $0.5 \mathrm{ml}$ of each bacterial suspension was inoculated into $50 \mathrm{ml}$ of NB medium to an initial concentration $\left(\mathrm{OD}_{600}=0.01\right)$. Growth was monitored by measuring the $\mathrm{OD}_{600}$ against the NB medium blank every $4 \mathrm{~h}$ after inoculation, and all inoculated samples were grown at $28^{\circ} \mathrm{C}$ until the stationary phase was achieved. The biological experiments were performed three times and each involved three replicates.

EPS production and swarming motility assays. Assays for testing swarming motility and EPS production were performed according to previous studies (Guo et al. 2012; Qian et al. 2013b; Zheng et al. 2016), with minor modifications. Briefly, to measure EPS production, fresh cultures of $X$. oryzae pv. oryzae strains were inoculated into $50 \mathrm{ml}$ of $\mathrm{NB}$ medium at a starting $\mathrm{OD}_{600}$ of 0.01 . After shaking at $220 \mathrm{rpm}$ at $28^{\circ} \mathrm{C}$ for approximately 5 days, the supernatants were collected via centrifugation at $12,000 \times g$ for $10 \mathrm{~min}$, and EPS was precipitated from the supernatant by the addition of two volumes of ethanol. The EPS pellets were then dried at $60^{\circ} \mathrm{C}$ to a constant weight, which was recorded as an estimate of the EPS. All values were expressed relative to the volume. The biological experiments were performed three times and each involved three replicates.

For the swarming motility assays, $X$. oryzae pv. oryzae strains were cultured in $\mathrm{NB}$ medium at $28^{\circ} \mathrm{C}$, and the concentration of each culture was adjusted to $\mathrm{OD}_{600}=1.0$. Next, $3 \mu$ of the bacterial culture were spotted onto the semisolid NA plates with $0.6 \%$ (wt/vol) agar. The plates were incubated at $28^{\circ} \mathrm{C}$ for approximately 5 days, and the diameter of the motility halo was recorded as an estimate of cell motility. The biological experiments were performed three times and each involved three replicates.

Stress tolerance assays. Agar plate-based assays for determining the stress tolerance were performed as described previously, with minor modifications ( $\mathrm{Li}$ and Wang 2012; Qian et al. 2008). Briefly, $X$. oryzae pv. oryzae strains were cultured in NB medium at $28^{\circ} \mathrm{C}$ to the exponential phase; then, bacterial suspensions were adjusted to a concentration of $\mathrm{OD}_{600}=1.0$, which was defined as the initial cultures $\left(1 \times, \mathrm{OD}_{600}=1.0\right)$. After diluting the initial cultures 5 -fold ( $5 x)$ and 25 -fold $(25 \times), 3 \mu$ of the initial and diluted cultures for each strain were spotted onto NA plates or NA plates containing $\mathrm{H}_{2} \mathrm{O}_{2}$ at concentrations of 0.1 and $0.15 \mathrm{mM}$, sodium dodecyl sulfate (SDS) at concentrations of 0.01 and $0.0125 \%$ (wt/vol), $\mathrm{CuSO}_{4}$ at concentrations of 0.25 and $0.5 \mathrm{mM}$, and $\mathrm{NaCl}$ at concentrations of 0.2 and $0.3 \mathrm{M}$, respectively. The growth phenotype of the WT PXO99A on each plate were used as a control. All plates were incubated at $28^{\circ} \mathrm{C}$ for 3 to 5 days until the colony formed by strain PXO99A at the lowest dilution $(25 \times)$ was visible on each plate, followed by photography. The experiments were performed three times and each involved three replicates.

Statistical analysis. All data were analyzed using SPSS v.19.0 (SPSS Inc.). Significant differences in virulence, bacterial growth, EPS production, swarming motility, and gene expression among different strains were determined via the hypothesis test of percentages $(t$ test).

\section{RESULTS}

Identification of 15 potential TDTP in $X$. oryzae pv. oryzae. To identify potential TDTP in X. oryzae pv. oryzae, the extracellular proteins from the WT and the tat $C$ in-frame deletion mutant $(\Delta t a t C)$ were prepared for comparative proteomics, as described in detail in Materials and Methods. Strain $\Delta$ tatC was generated in this study and its virulence deficiency was validated, in agreement with our previous finding derived from the $t a t C$ disrupted mutant (Chen et al. 2009). The results of 2-DE showed that, in total, 48 secreted protein spots that displayed higher levels (>twofold) in WT compared with $\Delta t a t C$ were identified (Supplementary Fig. S3). Among them, 19 protein spots with upregulated levels above the threshold ratio of 5.0 were further analyzed via MALDI-TOF-MS. This led to identification of 10 proteins according to the genome of strain PXO99A (Table 1). Two programs, PSORTb v3.0 and CELLO v2.5, were used to predict the cellular localization of the identified 10 proteins, and the results demonstrated that all of them were located in the outer membrane or extracellular space, thus verifying the reliability of our results. Further bioinformatics analyses revealed that functions of the 10 proteins were classified into six categories (Table 1), including intracellular trafficking, secretion, and vesicular transport; extracellular structures (1 protein); inorganic ion transport and metabolism ( 2 proteins); cell motility (1 protein); lipid catabolic process (1 protein); cell wall, membrane, and envelope biogenesis (1 protein); and function unknown (4 proteins). Surprisingly, 8 of the 10 proteins were predicted to be T2SS-related proteins with Sec signal peptides at their N-terminal regions, whereas PXO_02047, a type VI secretion system (T6SS)-associated Hcp family protein, was predicted to lack the $\mathrm{N}$-terminal signal peptide using the PREDTAT and SignalP v4.0 bioinformatics servers. It should be noted that only PXO_02671 (XadA), a T5SS-associated adhesin protein, possessed a predicted twin-arginine motif sequence (RRHRLA) in its $\mathrm{N}$-terminal region when analyzed using the PRED-TAT server (Table 1; Supplementary Table S4). It is worth mentioning that the transcriptional levels of the 10 TDTP-encoding genes were not affected in the tatC mutant compared with the WT as determined by quantitative reverse-transcription PCR (Supplementary Fig. S4), suggesting their changes in extracellular protein levels are not due to their alternation in transcription under the tested conditions.

In addition to the comparative proteomics described above, we also employed detailed bioinformatics analyses to further predict TDTP in $X$. oryzae pv. oryzae. For this purpose, the genome sequence of strain PXO99A was analyzed to discover potential TDTP via three major programs, including PRED-TAT, TATFIND v1.4, and TatP v1.0. In all, 25, 52, and 30 proteins with Tat motifs 
were predicted as TDTP using TATFIND v1.4, PRED-TAT, and TatP v1.0, respectively (Fig. 1). However, due to the limitation and possibility of each program in generating a degree of false-positive or false-negative predictions (Bagos et al. 2010; Bendtsen et al. 2005; Joshi et al. 2010), the distributions of predicted TDTP from the three programs exhibited large variation and only partial overlap (Fig. 1). Five proteins (PXO_02203, PXO_03132, PXO_01547, PXO_04621, and PXO_01470) were all predicted by use of each program and recognized as reliable or confident TDTP candidates (Fig. 1; Table 2). Such a strategy has been previously adopted and experimentally validated in other bacterial systems for predicting TDTP (McDonough et al. 2008; Widdick et al. 2006). Among them, PXO_03132 is a copper resistance protein A (CopA) with a homolog in P. syringae pv. tomato (Bronstein et al. 2005) that is important for copper homeostasis. PXO_01547, a nonhemolytic phospholipase $\mathrm{C}$, is predicted to be a secreted protein in PXO99A, and its homolog (PlcN) has been demonstrated to function in P. aeruginosa pathogenesis (Ochsner et al. 2002). PXO_04621 is homologous to glucose-fructose oxidoreductase, which has been demonstrated to have a physiological role in the production of sorbitol for osmoprotection in Zymomonas mobilis (Nurizzo et al. 2001). More importantly, the homologs of PXO_01547, PXO_03132, and PXO_04621 in the abovementioned bacteria have also been experimentally confirmed to be Tat dependent (Bronstein et al. 2005; Nurizzo et al. 2001; Ochsner et al. 2002), supporting the reliability and high performance of our prediction approaches.
To conclude, in this study, 10 and 5 proteins were identified as $X$. oryzae pv. oryzae TDTP candidates by using comparative proteomics and bioinformatics analyses, respectively. These 15 proteins were selected for further study (see below).

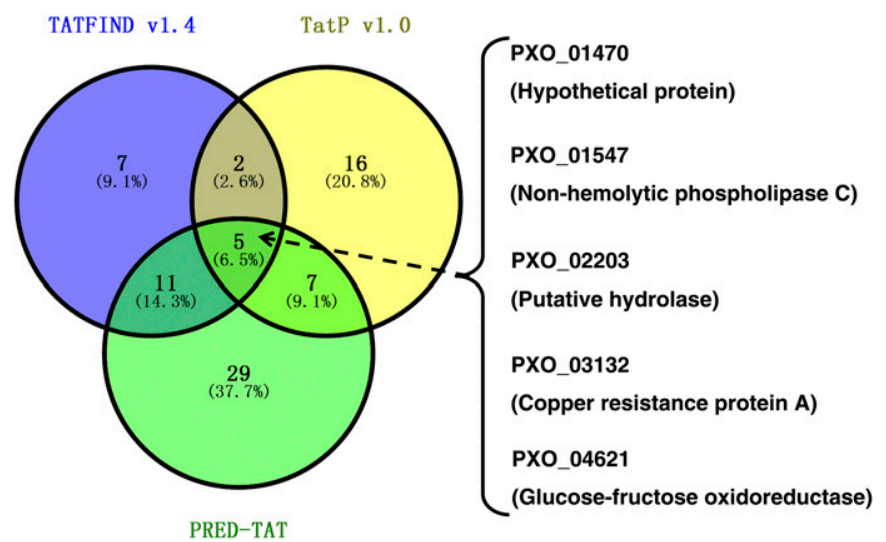

Fig. 1. Venn diagram indicating the distribution of potential twin-arginine translocation (Tat) substrates predicted using three major bioinformatics programs (TATFIND v1.4, TatP v1.0, and PRED-TAT) in Xanthomonas oryzae pv. oryzae PXO99A. In total, 77 predicted Tat substrates were successfully annotated. Only five proteins (indicated with arrow) were simultaneously predicted by all three bioinformatics programs.

TABLE 1. Identification of 10 extracellular proteins with a greater than fivefold difference in Xanthomonas oryzae pv. oryzae compared with $\Delta t a t C$

\begin{tabular}{|c|c|c|c|c|c|c|c|c|c|c|c|c|}
\hline $\mathrm{Cat}^{\mathrm{a}}$ & Spot & Score $^{b}$ & $\operatorname{Cov}(\%)^{\mathrm{c}}$ & $\begin{array}{l}\text { Fold change } \\
(\mathrm{WT} / \Delta \mathrm{T})^{\mathrm{d}}\end{array}$ & $\begin{array}{l}\text { Function, } \\
\text { similarity }\end{array}$ & $\begin{array}{c}\text { Functional } \\
\text { categorization }^{\mathrm{e}}\end{array}$ & $\begin{array}{l}\text { Accession } \\
\text { number }\end{array}$ & $\begin{array}{l}\text { Protein } \\
\text { code }\end{array}$ & $\begin{array}{c}\text { Signal } \\
\text { peptide }^{f}\end{array}$ & Pred $^{g}$ & $\underset{(\mathrm{cal})^{\mathrm{h}}}{\mathrm{pI}}$ & $\begin{array}{c}M_{\mathrm{r}}(\mathrm{cal}) \\
\mathrm{KD}^{\mathrm{h}}\end{array}$ \\
\hline \multirow[t]{4}{*}{1} & B01 & 212 & 17 & 27.6335 & $\begin{array}{l}\text { Xanthomonas } \\
\text { adhesin-like } \\
\text { protein A (XadA) }\end{array}$ & $\begin{array}{l}\text { Intracellular trafficking, } \\
\text { secretion, and } \\
\text { vesicular transport; } \\
\text { extracellular } \\
\text { structures }\end{array}$ & gi||188523050 & PXO_02671 & Tat & OM, Ex & 5.01 & 119.7 \\
\hline & B02 & 207 & 18 & 1000000 & $\ldots$ & $\ldots$ & $\ldots$ & $\ldots$ & Tat & $\ldots$ & $\ldots$ & $\ldots$ \\
\hline & B03 & 218 & 16 & 1000000 & $\ldots$ & $\ldots$ & $\ldots$ & $\ldots$ & Tat & $\ldots$ & $\ldots$ & $\ldots$ \\
\hline & B06 & 378 & 22 & 20.7356 & $\ldots$ & $\ldots$ & $\ldots$ & $\ldots$ & Tat & $\ldots$ & $\ldots$ & $\ldots$ \\
\hline 2 & В07 & 404 & 35 & 5.30965 & $\begin{array}{l}\text { TonB-dependent } \\
\text { outer membrane } \\
\text { receptor }\end{array}$ & $\begin{array}{l}\text { Inorganic ion } \\
\text { transport and } \\
\text { metabolism }\end{array}$ & gi|188520202 & PXO_04865 & $\mathrm{Sec}$ & $\mathrm{OM}$ & 5.14 & 87.7 \\
\hline 3 & B08 & 371 & 30 & 6.20421 & $\begin{array}{l}\text { TonB-dependent } \\
\text { receptor }\end{array}$ & $\ldots$ & gi||188522758 & PXO_02415 & $\mathrm{Sec}$ & $\ldots$ & 5.02 & 87.4 \\
\hline 4 & B19 & 258 & 38 & 5.62549 & Flagellin (FliC) & Cell motility & gi|188521216 & PXO_01001 & $\mathrm{Sec}$ & $\mathrm{Ex}, \mathrm{OM}$ & 5.08 & 39.4 \\
\hline 6 & B26 & 165 & 12 & 6.85856 & $\begin{array}{l}\text { Tetratricopeptide } \\
\text { repeat domain } \\
\text { protein }\end{array}$ & Unknown function & gi|188518729 & PXO_03477 & $\mathrm{Sec}$ & $\ldots$ & 8.73 & 43.2 \\
\hline 7 & B28 & 388 & 40 & 5.62907 & $\begin{array}{l}\text { Hypothetical } \\
\text { protein }\end{array}$ & Unknown function & gi|188519088 & PXO_03841 & $\mathrm{Sec}$ & $\ldots$ & 5.82 & 31.1 \\
\hline 8 & B39 & 283 & 41 & 9.7861 & $\begin{array}{l}\text { Predicted } \\
\text { methyltransferase }\end{array}$ & Unknown function & gi|188523596 & PXO_03273 & $\mathrm{Sec}$ & $\ldots$ & 9.13 & 30.8 \\
\hline \multirow[t]{3}{*}{9} & B44 & 269 & 81 & 6.88195 & Hcp family protein & Unknown function & gi|188522385 & PXO_02047 & None & Ex, Peri & 5.76 & 18.1 \\
\hline & B45 & 293 & 80 & 20.9071 & $\ldots$ & $\ldots$ & $\ldots$ & $\ldots$ & None & $\ldots$ & $\ldots$ & $\ldots$ \\
\hline & B46 & 360 & 76 & 16.325 & $\ldots$ & $\ldots$ & $\ldots$ & $\ldots$ & None & & $\ldots$ & $\ldots$ \\
\hline 10 & B30 & 287 & 31 & 6.0626 & $\begin{array}{l}\text { OmpA family } \\
\text { outer membrane } \\
\text { protein }\end{array}$ & $\begin{array}{l}\text { Cell wall, membrane, } \\
\text { envelope biogenesis }\end{array}$ & gi|188522869 & PXO_02523 & $\mathrm{Sec}$ & $\mathrm{OM}$ & 4.88 & 39.5 \\
\hline
\end{tabular}

a Catalog number

b Scores are based on the Mowse search. Protein scores greater than 82 are significant $(P<0.05)$.

c Sequence coverage.

d WT = wild-type PXO99A and $\Delta \mathrm{T}=$ tat $C$ mutant

e The functional catalog was performed using protein BLAST and eggNOG v4.5. Names and codes of identified proteins are according to genomic annotation of $X$. oryzae pv. oryzae PXO99A.

f Twin-arginine (Tat) and secretory (Sec) signal peptides was predicted by PRED-TAT, TatP v1.0, and SignalP v4.0.

g Bacterial protein subcellular localization prediction was performed using PSORTb v3.0 and CELLO v2.5. OM = outer membrane, Ex = extracellular, and Peri $=$ periplasmic.

${ }^{\mathrm{h}}$ Computation of the theoretical protein isoelectric point $(\mathrm{pI})$ and molecular weight $\left(M_{\mathrm{r}}\right)$ for selected proteins was performed using the ExPASy tool. 
and disease symptom development in Xanthomonas spp. (Büttner and Bonas 2010; Zheng et al. 2016). Moreover, our previous findings also documented that the disruption of tat $C$ significantly reduced EPS production and cell motility in strain PXO99A (Chen et al. 2009). These phenomena prompted us to investigate whether 15 TDTP are also involved in EPS production and swarming ability. Under test conditions, only $\triangle P X O \_02671$ exhibited significantly increased EPS production compared with that of the WT, whereas this change could be rescued to WT levels by in trans complementation (Fig. 5A). Compared with the WT, the remaining 14 mutants had small changes in this function. As a control, the tat $C$ deletion mutant $(\triangle t a t C)$ exhibited a remarkable decrease in EPS production, in agreement with our earlier findings (Chen et al. 2009). Collectively, these results suggested that PXO_02671 was involved in regulating EPS production in strain PXO99A.

The results of the swarming motility assay showed that the halo diameters of motility zones from $\triangle P X O \_02523$ and $\triangle P X O \_02671$ were significantly less than that of the WT. This deficiency from both mutants could be fully or partially rescued to WT levels by in trans complementation (Fig. 5B). These results indicated that PXO_02523 and PXO_02671 are involved in modulating the swarming motility in strain PXO99A. Furthermore, we also showed that TatC plays a regulatory role in $X$. oryzae pv. oryzae swarming motility. The remaining mutants showed only slight changes in swarming motility compared with that of the WT under the test conditions.

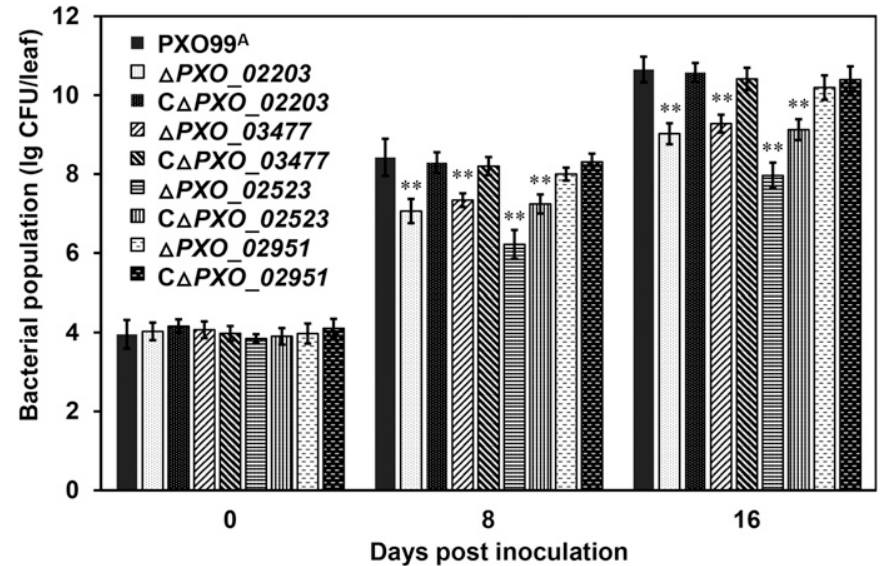

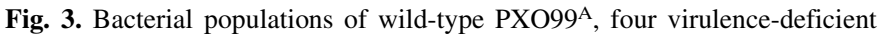
mutants, and their complemented strains in susceptible rice leaves. Xanthomonas oryzae pv. oryzae strains were inoculated onto 5- to 6-week-old IR24 leaves at a concentration of optical density at $600 \mathrm{~nm}=0.5$ using the leafclipping method. Inoculated leaves for extracting bacteria were harvested every 8 days $(0,8$, and 16 days postinoculation), homogenized in sterile water, and serially diluted to count the CFU on nutrient broth agar plates. Bacterial populations were presented as $1 \mathrm{~g}$ of CFU per leaf. Each value represents the average bacterial population \pm standard deviation from three independent experiments. Asterisks indicate significant differences compared with the wild type $(t$ test, ** indicates $P<0.01$ ).

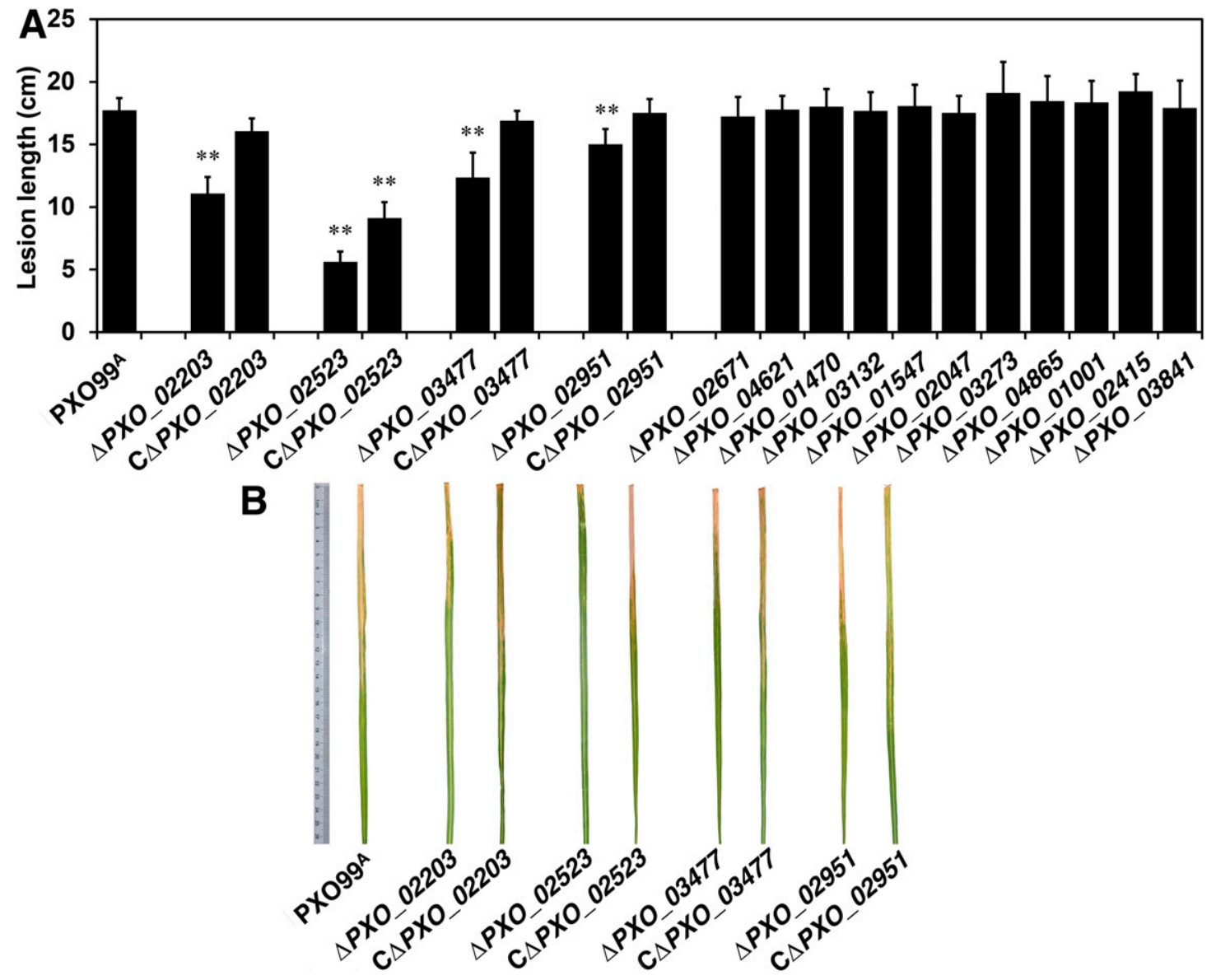

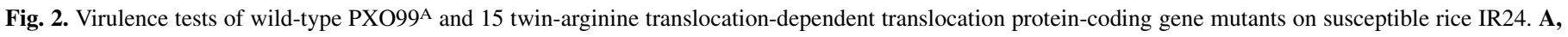

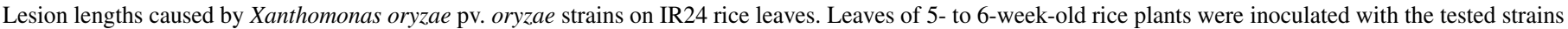

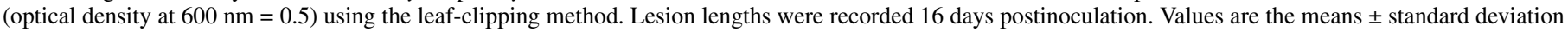

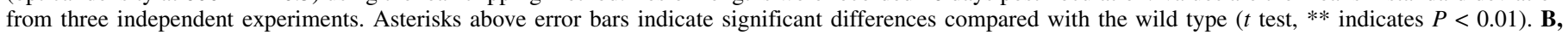

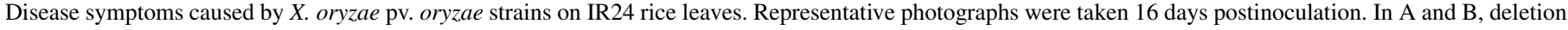

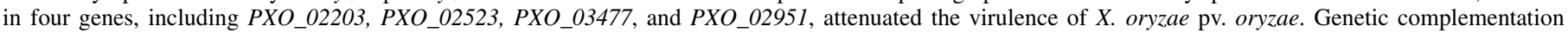

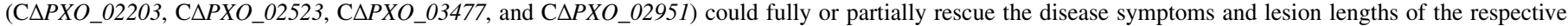
mutants. 

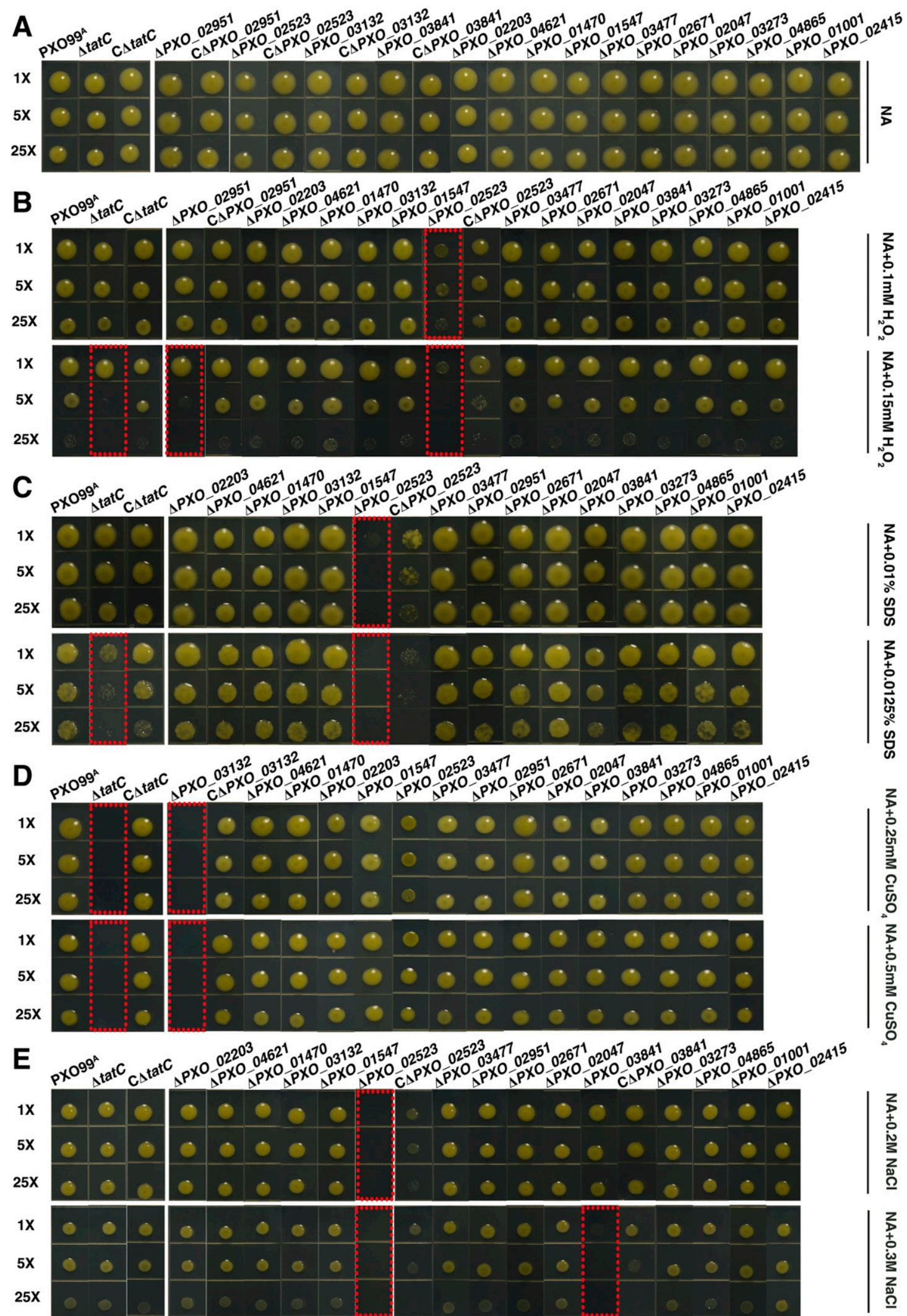

Fig. 4. Determination of the roles of the twin-arginine translocation (Tat) pathway and 15 Tat-dependent translocation proteins (TDTP) in multiple stress tolerance using plate-based assays. The Xanthomonas oryzae pv. oryzae strains were precultured to the exponential phase of the indicated value $($ optical density at $600 \mathrm{~nm}=$ 1.0, initial culture) in nutrient broth (NB) medium, and the initial culture (1x) was diluted 5-fold $(5 \times)$ and 25 -fold (25x). The initial culture and diluted cultures for each strain ( $3 \mu \mathrm{l}$ each) were spotted onto NB agar (NA) plates and NA plates containing multiple stressors at the indicated concentrations. A, No growth defects were observed among PXO99A,$\triangle t a t C$, and 15 TDTP-coding gene mutants on NA plates (experimental control). B, Mutations in tatC, PXO_02951, and PXO_02523 resulted in reduced tolerance of $X$. oryzae pv. oryzae against oxidative stress. C, Mutations in tatC and PXO_02523 resulted in reduced tolerance of $X$. oryzae pv. oryzae against sodium dodecyl sulfate stress. D, Mutations in tatC and PXO_03132 resulted in reduced tolerance of $X$. oryzae pv. oryzae against copper stress. E, Mutations in PXO_02523 and PXO_03841 resulted in reduced tolerance of X. oryzae pv. oryzae against sodium stress. In A, B, C, D, and E, genetic complementation could fully or partially rescued the stress tolerance of the mentioned mutants to wild-type levels. All plates were incubated at $28^{\circ} \mathrm{C}$, and representative colony morphologies were photographed 3 to 5 days after spotting on agar plates. The experiment was repeated at least three times, with similar results. 


\section{DISCUSSION}

In this study, we have, for the first time, identified 15 potential TDTP via comparative proteomics and detailed bioinformatics analyses, and dissected their roles in virulence and multiple stress adaption in the economically significant phytopathogenic bacterium $X$. oryzae pv. oryzae. The findings of this work led us to discover three previously uncharacterized virulence determinants that are required for full virulence in $X$. oryzae pv. oryzae, including PXO_02203, PXO_03477, and PXO_02523, all of which are conservatively distributed in the genus of Xanthomonas. We also provided the first evidence to show that different TDTP play differential roles in multiple stress tolerance (PXO_02523, PXO_02951, PXO_03132, and PXO_03841), EPS production (PXO_02671), and swarming motility (PXO_02523 and PXO_02671). These phenotypes are considered to be associated with $X$. oryzae $\mathrm{pv}$. oryzae infection and environmental adaption. Therefore, these results, along with our earlier findings, raise the possibility that the $X$. oryzae pv. oryzae Tat pathway controls virulence and stress adaption, probably via its dependent translocation proteins, which provides new insights into the working mechanism of the Tat pathway in $X$. oryzae pv. oryzae.

In the present study, we identified 10 potential TDTP in $X$. oryzae pv. oryzae via comparative proteomics. Surprisingly, excluding PXO_02671 (XadA), which was predicted to have a Tat signal peptide, the remaining eight proteins were found to contain Sec but not the Tat signal peptide (Table 1). This situation has also been observed in other bacterial pathogens, where the majority of proteins present in significantly reduced amounts or absent in the exoproteome of $\triangle$ tatC were not predicted to contain Tat signal peptides as well (Ball et al. 2016; Joshi et al. 2010; Widdick et al. 2006). These findings collectively raise an interesting question: why are an unexpectedly high number of proteins containing Sec but not Tat signal peptides easy to detect in the Tat-dependent exoproteome? The possible explanations for this query could be summarized as follows. (i) Technical limitation. It is likely that the significance threshold (>fivefold) used for filtering ambiguous protein spots and the limited ability of 2-DE to detect proteins with a low abundance prevented us from discovering "true" TDTP that contain Tat signal peptides. (ii) Cultural condition. Several laboratories have demonstrated that the number and types of extracellular TDTP identified by proteomics under different culture conditions can vary greatly (Ball et al. 2016; Bronstein et al. 2004; Joshi et al. 2010), suggesting that some true TDTP are most likely poorly expressed or secreted using the test nutritional condition in the present study. (iii) 'Hitchhiker' mechanism. The hitchhiker mechanism of the Tat pathway has been demonstrated to translocate proteins lacking Tat signal peptides across the cytoplasmic membrane by forming heteromeric protein complexes with specific Tat substrates (Tullman-Ercek et al. 2007). Therefore, the Tat pathway may contribute directly or indirectly to the translocation of specific Sec substrate proteins (Bronstein et al. 2004). Moreover, inactivation of the Tat pathway has also been demonstrated to have pleiotropic effects on a variety of cellular processes, including alterations of the Sec pathway (Bronstein et al. 2004; Joshi et al. 2010), which may subsequently result in reduced secretion of Secdependent proteins in $\triangle t a t C$. Remarkably, of the 10 identified TDTP, 2 (PXO_02951 and PXO_01001) of their homologs, LipA and flagellin (FliC), were demonstrated to be secreted via the Tat pathway (Kouwen et al. 2009) or have been identified in the Tatdependent exoproteome (Ball et al. 2016; Pradel et al. 2003) in other bacterial system under specific conditions, thus supporting our abovementioned hypothesis.

One of the important finding of the present study is to discover three previously uncharacterized virulence determinants in $X$. oryzae pv. oryzae. The first one is PXO_02203, which is annotated as a

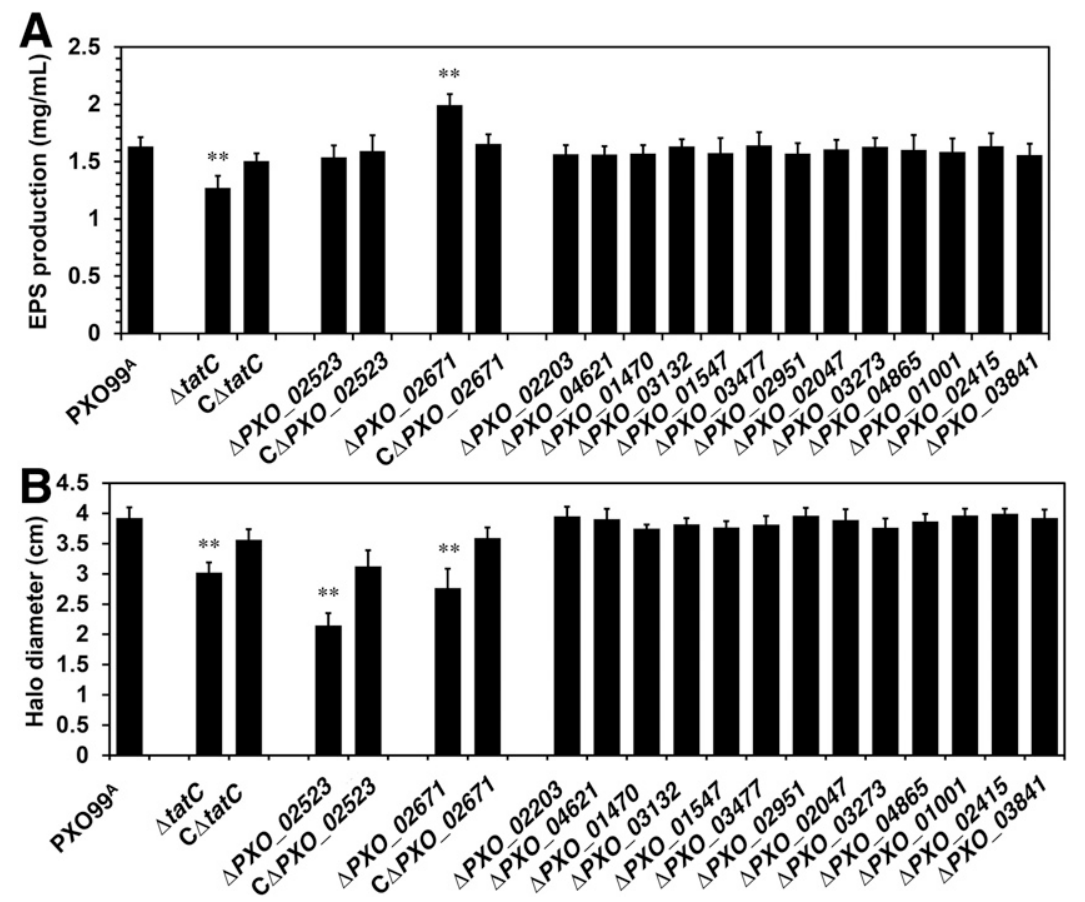

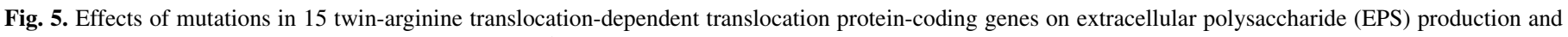

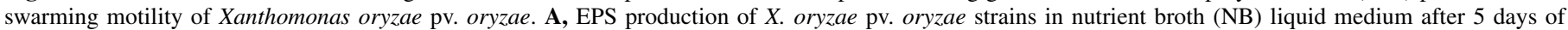

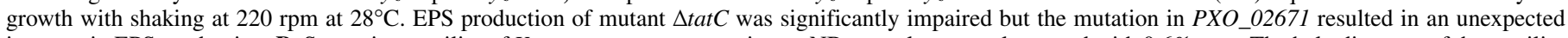

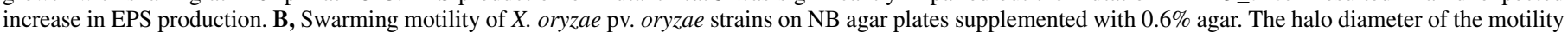

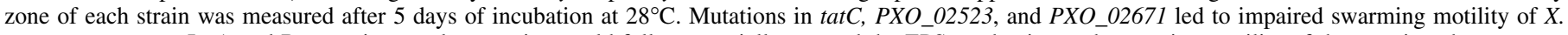

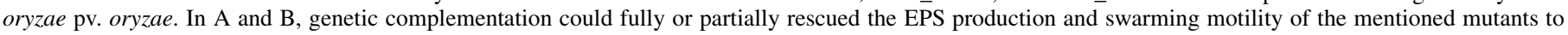

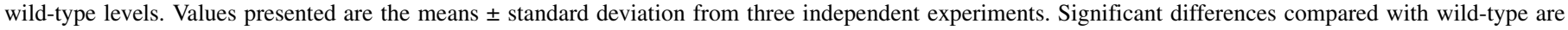
indicated by $* *$ ( $t$ test, $P<0.01)$. 
putative hydrolase with similarity to the Pseudoalteromonas carrageenovora arylsulfatase (AtsA) or the E. coli ElaC domaincontaining protein. In $E$. coli, the enzymatic analysis confirmed that this protein does not possess AtsA activity but, rather, has zincdependent phosphodiesterase activity that participates in tRNA $3^{\prime}$ processing (Vogel et al. 2002). To our knowledge, the AtsA or ElaC domain-containing proteins were rarely linked to virulence; thus, addressing the precise mechanism of PXO_02203 in virulence deserves future study. The second one, PXO_03477, is annotated as a tetratricopeptide repeat (TPR) domain protein. The TPR motif usually serves as a protein-protein interaction module and as a multiprotein complex mediator (Cerveny et al. 2013). Notably, several TPR domain-containing proteins in bacterial pathogens have been reported to be associated with virulence-related processes (Cerveny et al. 2013), which can be regarded as supporting evidence for our results. The third one is PXO_02523, which is predicted to be an OmpA family outer membrane protein. The OmpA-like proteins in bacteria mainly function in the maintenance of membrane structure and stability, and homologs of OmpA have been demonstrated to be required for pathogenicity in several plant and animal pathogens (Confer and Ayalew 2013; Rott et al. 2009). However, we demonstrated herein, for the first time, that the OmpA homolog ( $\mathrm{PXO}_{-}$02523) in $X$. oryzae pv. oryzae is required for bacterial fitness and colonization in infected rice leaves, and it has a critical role in multiple types of stress tolerance and motility. Furthermore, in contrast, 2 of the 15 TDTP, flagellin (PXO_01001) and T6SS Hcp family protein (PXO_02047), which have homologs that are confirmed virulence factors in the bacterial pathogens $E$. coli $\mathrm{O} 157$ : H7 (Pradel et al. 2003) and Pseudomonas aeruginosa (Mougous et al. 2006), did not involve pathogenicity in X. oryzae pv. oryzae under the test conditions, thus suggesting that the involvement of certain TDTP in virulence could vary in different bacterial pathogens.

The second important finding of this work is to show that multiple TDTP contribute differentially to $X$. oryzae pv. oryzae adaption under various environmental stresses, which provides evidence to connect the differential involvement of Tat pathways in these functions. In particular, we demonstrated that only the mutants $\triangle$ tat $C$ and $\triangle P X O \_03132$ had impaired copper tolerance but PXO_03132 (CopA) was not required for X. oryzae pv. oryzae virulence under laboratory conditions. In $P$. aeruginosa and $P$. syringae pv. tomato, both homologs of TatC were also reported to be involved in copper tolerance. These studies also speculated that the increased copper sensitivity of $\triangle t a t C$ presumably resulted from the incorrect translocation of the Tat substrate CopA (Bronstein et al. 2005; Ochsner et al. 2002). Testing such a hypothesis in $X$. oryzae pv. oryzae will facilitate addressing the detailed relationship between the Tat pathway and PXO_03132 in adaption to copper stress. Moreover, we also found that $\triangle t a t C$ and $\triangle P X O \_02951(\triangle l i p A)$ were associated with pathogenicity and $\mathrm{H}_{2} \mathrm{O}_{2}$ tolerance in $X$. oryzae $\mathrm{pv}$. oryzae. In fact, the LipA homologs have been reported to be secreted lipolytic enzymes that are expressed in planta and contribute to pathogenesis during infection by several pathogens (Aparna et al. 2009; Tamir-Ariel et al. 2012). In this study, based on the above findings and data obtained for PXO_02951 (LipA) in the proteomics study, we hypothesized that the reduced secretion of PXO_02951 (LipA) in $\Delta t a t C$ was most likely one of the reasons explaining the impairment of virulence and $\mathrm{H}_{2} \mathrm{O}_{2}$ tolerance of $\Delta t a t C$ in $X$. oryzae pv. oryzae. For the impaired SDS tolerance observed in $\triangle t a t C$, some studies in $E$. coli (Ize et al. 2003) and Ralstonia solanacearum (González et al. 2007) indicate that these phenotypes (SDS hypersensitivity) arise as a result of defects in the integrity of the cell envelope in the Tat mutant. Coincidently, we found that mutation in PXO_02523, which is implicated in maintaining the integrity of the outer membrane, exhibited impaired virulence and increased sensitivity to $\mathrm{H}_{2} \mathrm{O}_{2}$ and SDS, similar to the phenotypes in $\triangle$ tatC in $X$. oryzae pv. oryzae, thus indicating that the reduced amount of PXO_02523 observed in the exoproteome of $\triangle t a t C$ was likely a contributor for the Tat pathway to withstand $\mathrm{H}_{2} \mathrm{O}_{2}$ stress and infection. Finally, it is also worth mentioning that PXO_02523 and PXO_03841 (lipid metabolismassociated) were required for sodium tolerance but $\triangle t a t C$ was not defective in this function, thus suggesting that a Tat-independent mechanism may be used by PXO_02523 and PXO_03841 in adaption to sodium stress in $X$. oryzae pv. oryzae.

Adhesins are known to play a crucial role in the attachment of plant-pathogenic bacteria to specific host surfaces (Büttner and Bonas 2010). Particularly, the Xanthomonas adhesin-like protein A (XadA) has been demonstrated to be required for early attachment of BXO43 to rice leaves (Das et al. 2009). Extracellular levels of XadA (PXO_02671) are shown to be regulated by the Tat pathway in strain PXO99A; thus, along with earlier reports described above, it is possible that the Tat pathway may contribute to $X$. oryzae pv. oryzae attachment on the rice leaf surface via XadA (PXO_02671). Indeed, our results supported this hypothesis, because we found that, compared with the WT, both $\triangle$ tatC and $\triangle P X O \_02671$ exhibited a significant deficiency in bacterial adhesion on rice leaves via confocal laser-scanning microscopy and crystal violet staining analyses (Supplementary Fig. S6). These results suggested that the Tat pathway may affect $X$. oryzae pv. oryzae adhesion on rice leaves by modulating the biological behavior of PXO_02671. We also noticed that $\triangle P X O \_02671$ exhibited a fitness defect on the rice leaf surface, suggesting an important role of bacterial adhesion in the epiphytic fitness of $X$. oryzae pv. oryzae. Furthermore, bacterial adhesion has also been reported to be implicated in the epiphytic fitness of $X$. fuscans subsp. fuscans (Darsonval et al. 2009), which could be regarded as a supporting evidence for our result. Notably, in $X$. oryzae pv. oryzae $\mathrm{BXO} 43$, the $x a d A$ mutant is deficient in the ability to cause disease via surface inoculation (not by wound inoculation) (Das et al. 2009), indicating that bacterial adhesion and epiphytic fitness were likely contributors to the development of bacterial leaf blight disease.

EPS and swarming motility are important virulence determinants in Xanthomonas spp. (Büttner and Bonas 2010; González et al. 2013; Zheng et al. 2016). In this study, the mutation in PXO_02671 resulted in an increased level of EPS production. No significant reduction of EPS production was observed in the remaining 14 TDTP-coding gene mutants, indicating that additional factors rather than these 15 TDTP or cooperation between tested TDTP probably account for the reduced EPS production related to $\triangle$ tat $C$. In addition, $\triangle P X O \_02523$ exhibited impaired swarming motility, which may be one of the reasons for the attenuation of virulence of this mutant on host rice. We also observed that the absence of PXO_02671 induced a significant decrease in swarming motility. However, the swimming motility of $\triangle P X O \_02671$ was not impaired compared with the WT (data not shown). Such an observation for one certain protein playing different roles in swarming motility and swimming motility has also been reported in E. coli (Inoue et al. 2007). The mechanism underlying this phenomenon regarding PXO_02671 is worthy of future study. Remarkably, of 15 TDTP, we had an initial expectation that the flagellin protein FliC (PXO_01001), the homolog of which in E. coli is involved in a strongly repressed-swarming phenotype (Inoue et al. 2007), could explain the impaired virulence and decreased swarming motility of $\triangle t a t C$; however, we did not observe any significant difference in virulence and swarming motility between $\triangle P X O \_01001$ and the WT. This result suggests that inactivation of a single flagellin protein in PXO99A may not be enough to cause visible phenotype changes (i.e., swarming motility). Such a hypothesis has been highlighted in related studies, wherein the authors show that the single flagellin gene mutant $\Delta f l i C$ was still sufficient for forming swarming motility in Salmonella typhimurium (Harshey and Matsuyama 1994) and also exhibited WT virulence in X. campestris (Lee et al. 2003).

In summary, the present study shows that 15 TDTP have differential roles in virulence, colonization, attachment, stress tolerance, EPS production, and swarming motility in $X$. oryzae $\mathrm{pv}$. oryzae. Interestingly, similar defects in varying degrees in these 
phenotypes were also found in $\triangle t a t C$, indicating that the $X$. oryzae pv. oryzae Tat pathway most likely performs its multiple virulenceassociated functions by directly or indirectly coordinating the biological behaviors of one or more of the above-characterized TDTP. This is helpful to understand how the Tat pathway controls pathogenicity in X. oryzae pv. oryzae.

\section{ACKNOWLEDGMENTS}

This work was supported by National Natural Science Foundation of China (31571974 and 31371906), the grants from Jiangsu Academy of Agricultural Sciences (ZX(2017)1005) and the Special Fund for Agroscientific Research in the Public Interest (number 201303015).

\section{LITERATURE CITED}

Andrade, M. O., Farah, C. S., and Wang, N. 2014. The post-transcriptional regulator $r s m A / \operatorname{csr} A$ activates T3SS by stabilizing the 5' UTR of $h r p G$, the master regulator of hrp/hrc genes, in Xanthomonas. PLoS Pathog. 10: e 1003945.

Aparna, G., Chatterjee, A., Sonti, R. V., and Sankaranarayanan, R. 2009. A cell wall-degrading esterase of Xanthomonas oryzae requires a unique substrate recognition module for pathogenesis on rice. Plant Cell 21: 1860-1873.

Artimo, P., Jonnalagedda, M., Arnold, K., Baratin, D., Csardi, G., de Castro, E., Duvaud, S., Flegel, V., Fortier, A., Gasteiger, E., Grosdidier, A., Hernandez, C., Ioannidis, V., Kuznetsov, D., Liechti, R., Moretti, S., Mostaguir, K., Redaschi, N., Rossier, G., Xenarios, I., and Stockinger, H. 2012. ExPASy: SIB bioinformatics resource portal. Nucleic Acids Res. 40:W597-W603.

Bagos, P. G., Nikolaou, E. P., Liakopoulos, T. D., and Tsirigos, K. D. 2010. Combined prediction of Tat and Sec signal peptides with hidden Markov models. Bioinformatics 26:2811-2817.

Balder, R., Shaffer, T. L., and Lafontaine, E. R. 2013. Moraxella catarrhalis uses a twin-arginine translocation system to secrete the beta-lactamase BRO-2. BMC Microbiol. 13:140.

Ball, G., Antelmann, H., Imbert, P. R., Gimenez, M. R., Voulhoux, R., and Ize, B. 2016. Contribution of the twin arginine translocation system to the exoproteome of Pseudomonas aeruginosa. Sci. Rep. 6: Article 27675. doi: $10.1038 /$ srep27675

Bendtsen, J. D., Nielsen, H., Widdick, D., Palmer, T., and Brunak, S. 2005. Prediction of twin-arginine signal peptides. BMC Bioinf. 6:167.

Block, A., Li, G. Y., Fu, Z. Q., and Alfano, J. R. 2008. Phytopathogen type III effector weaponry and their plant targets. Curr. Opin. Plant Biol. 11:396-403.

Bronstein, P., Marrichi, M., and DeLisa, M. P. 2004. Dissecting the twinarginine translocation pathway using genome-wide analysis. Res. Microbiol. 155:803-810.

Bronstein, P. A., Marrichi, M., Cartinhour, S., Schneider, D. J., and DeLisa, M. P. 2005. Identification of a twin-arginine translocation system in Pseudomonas syringae pv. tomato DC3000 and its contribution to pathogenicity and fitness. J. Bacteriol. 187:8450-8461.

Büttner, D., and Bonas, U. 2010. Regulation and secretion of Xanthomonas virulence factors. FEMS Microbiol. Rev. 34:107-133.

Calhoun, L. N., Liyanage, R., Lay, J. O., Jr., and Kwon, Y. M. 2010. Proteomic analysis of Salmonella enterica serovar Enteritidis following propionate adaptation. BMC Microbiol. 10:249.

Cerveny, L., Straskova, A., Dankova, V., Hartlova, A., Ceckova, M., Staud, F., and Stulik, J. 2013. Tetratricopeptide repeat motifs in the world of bacterial pathogens: Role in virulence mechanisms. Infect. Immun. 81:629-635.

Chatterjee, S., and Sonti, R. V. 2002. rpfF mutants of Xanthomonas oryzae pv. oryzae are deficient for virulence and growth under low iron conditions. Mol. Plant-Microbe Interact. 15:463-471.

Chen, L., Hu, B., Qian, G., Wang, C., Yang, W., Han, Z., and Liu, F. 2009. Identification and molecular characterization of twin-arginine translocation system (Tat) in Xanthomonas oryzae pv. oryzae strain PXO99. Arch. Microbiol. 191:163-170

Confer, A. W., and Ayalew, S. 2013. The OmpA family of proteins: Roles in bacterial pathogenesis and immunity. Vet. Microbiol. 163:207-222.

Darsonval, A., Darrasse, A., Durand, K., Bureau, C., Cesbron, S., and Jacques, M. A. 2009. Adhesion and fitness in the bean phyllosphere and transmission to seed of Xanthomonas fuscans subsp. fuscans. Mol. Plant-Microbe Interact. 22:747-757.

Das, A., Rangaraj, N., and Sonti, R. V. 2009. Multiple adhesin-like functions of Xanthomonas oryzae pv. oryzae are involved in promoting leaf attachment, entry, and virulence on rice. Mol. Plant-Microbe Interact. 22:73-85.

De Buck, E., Lammertyn, E., and Anne, J. 2008. The importance of the twinarginine translocation pathway for bacterial virulence. Trends Microbiol. $16: 442-453$
DeFeyter, R., Kado, C. I., and Gabriel, D. W. 1990. Small, stable shuttle vectors for use in Xanthomonas. Gene 88:65-72.

González, E. T., Brown, D. G., Swanson, J. K., and Allen, C. 2007. Using the Ralstonia solanacearum Tat secretome to identify bacterial wilt virulence factors. Appl. Environ. Microbiol. 73:3779-3786.

González, J. F., Myers, M. P., and Venturi, V. 2013. The inter-kingdom solo OryR regulator of Xanthomonas oryzae is important for motility. Mol. Plant Pathol. 14:211-221.

Guo, Y., Zhang, Y., Li, J. L., and Wang, N. 2012. Diffusible signal factormediated quorum sensing plays a central role in coordinating gene expression of Xanthomonas citri subsp. citri. Mol. Plant-Microbe Interact. 25:165-179.

Ham, J. H. 2013. Intercellular and intracellular signalling systems that globally control the expression of virulence genes in plant pathogenic bacteria. Mol. Plant Pathol. 14:308-322.

Harshey, R. M., and Matsuyama, T. 1994. Dimorphic transition in Escherichia coli and Salmonella typhimurium: Surface-induced differentiation into hyperflagellate swarmer cells. Proc. Natl. Acad. Sci. USA 91:8631-8635.

Hitchcock, A., Hall, S. J., Myers, J. D., Mulholland, F., Jones, M. A., and Kelly, D. J. 2010. Roles of the twin-arginine translocase and associated chaperones in the biogenesis of the electron transport chains of the human pathogen Campylobacter jejuni. Microbiology 156:2994-3010.

Huerta-Cepas, J., Szklarczyk, D., Forslund, K., Cook, H., Heller, D., Walter, M. C., Rattei, T., Mende, D. R., Sunagawa, S., Kuhn, M., Jensen, L. J., von Mering, C., and Bork, P. 2016. eggNOG 4.5: A hierarchical orthology framework with improved functional annotations for eukaryotic, prokaryotic and viral sequences. Nucleic Acids Res.: D286-D293.

Inoue, T., Shingaki, R., Hirose, S., Waki, K., Mori, H., and Fukui, K. 2007. Genome-wide screening of genes required for swarming motility in Escherichia coli K-12. J. Bacteriol. 189:950-957.

Ize, B., Stanley, N. R., Buchanan, G., and Palmer, T. 2003. Role of the Escherichia coli Tat pathway in outer membrane integrity. Mol. Microbiol. 48:1183-1193.

Jeong, K., Kim, G., Kim, W., and Cha, J. 2008. Clp mediates signal transduction for xylanase and motility, not for biofilm formation in Xanthomonas oryzae pv. oryzae. (Abstr.) Phytopathology 98:S74.

Jha, G., Rajeshwari, R., and Sonti, R. V. 2007. Functional interplay between two Xanthomonas oryzae pv. oryzae secretion systems in modulating virulence on rice. Mol. Plant-Microbe Interact. 20:31-40.

Joshi, M. V., Mann, S. G., Antelmann, H., Widdick, D. A., Fyans, J. K., Chandra, G., Hutchings, M. I., Toth, I., Hecker, M., Loria, R., and Palmer, T. 2010. The twin arginine protein transport pathway exports multiple virulence proteins in the plant pathogen Streptomyces scabies. Mol. Microbiol. 77:252-271.

Kouwen, T. R., van der Ploeg, R., Antelmann, H., Hecker, M., Homuth, G., Mader, U., and van Dijl, J. M. 2009. Overflow of a hyper-produced secretory protein from the Bacillus Sec pathway into the Tat pathway for protein secretion as revealed by proteogenomics. Proteomics 9:1018-1032.

Kudva, R., Denks, K., Kuhn, P., Vogt, A., Muller, M., and Koch, H. G. 2013. Protein translocation across the inner membrane of gram-negative bacteria: The Sec and Tat dependent protein transport pathways. Res. Microbiol. 164: 505-534.

Lee, B. M., Park, Y. J., Park, D. S., Kang, H. W., Kim, J. G., Song, E. S., Park, I. C., Yoon, U. H., Hahn, J. H., Koo, B. S., Lee, G. B., Kim, H., Park, H. S., Yoon, K. O., Kim, J. H., Jung, C. H., Koh, N. H., Seo, J. S., and Go, S. J. 2005. The genome sequence of Xanthomonas oryzae pathovar oryzae KACC10331, the bacterial blight pathogen of rice. Nucleic Acids Res. 33: 577-586.

Lee, M. C., Weng, S. F., and Tseng, Y. H. 2003. Flagellin gene fliC of Xanthomonas campestris is upregulated by transcription factor Clp. Biochem. Biophys. Res. Commun. 307:647-652.

Li, J., and Wang, N. 2012. The gps $X$ gene encoding a glycosyltransferase is important for polysaccharide production and required for full virulence in Xanthomonas citri subsp. citri. BMC Microbiol. 12:31.

Lu, Y., Rashidul, I. M., Hirata, H., and Tsuyumu, S. 2011. KdgR, an ICIR family transcriptional regulator, inhibits virulence mainly by repression of hrp genes in Xanthomonas oryzae pv. oryzae. J. Bacteriol. 193:6674-6682.

McDonough, J. A., McCann, J. R., Tekippe, E. M., Silverman, J. S., Rigel, N. W., and Braunstein, M. 2008. Identification of functional Tat signal sequences in Mycobacterium tuberculosis proteins. J. Bacteriol. 190:6428-6438.

Mougous, J. D., Cuff, M. E., Raunser, S., Shen, A., Zhou, M., Gifford, C. A., Goodman, A. L., Joachimiak, G., Ordonez, C. L., Lory, S., Walz, T., Joachimiak, A., and Mekalanos, J. J. 2006. A virulence locus of Pseudomonas aeruginosa encodes a protein secretion apparatus. Science 312:1526-1530.

Mount, D. W. 2007. Using the Basic Local Alignment Search Tool (BLAST). Cold Spring Harbor Protoc. 2007. doi:10.1101/pdb.top17

Niño-Liu, D. O., Ronald, P. C., and Bogdanove, A. J. 2006. Xanthomonas oryzae pathovars: Model pathogens of a model crop. Mol. Plant Pathol. 7:303-324. 
Nurizzo, D., Halbig, D., Sprenger, G. A., and Baker, E. N. 2001. Crystal structures of the precursor form of glucose-fructose oxidoreductase from Zymomonas mobilis and its complexes with bound ligands. Biochemistry 40:13857-13867.

Ochsner, U. A., Snyder, A., Vasil, A. I., and Vasil, M. L. 2002. Effects of the twin-arginine translocase on secretion of virulence factors, stress response, and pathogenesis. Proc. Natl. Acad. Sci. USA 99:8312-8317.

Patel, R., Smith, S. M., and Robinson, C. 2014. Protein transport by the bacterial Tat pathway. Biochim. Biophys. Acta 1843:1620-1628.

Petersen, T. N., Brunak, S., von Heijne, G., and Nielsen, H. 2011. SignalP 4.0: Discriminating signal peptides from transmembrane regions. Nat. Methods 8:785-786.

Pradel, N., Ye, C., Livrelli, V., Xu, J., Joly, B., and Wu, L. F. 2003. Contribution of the twin arginine translocation system to the virulence of enterohemorrhagic Escherichia coli O157:H7. Infect. Immun. 71:4908-4916.

Qian, G., Liu, C., Wu, G., Yin, F., Zhao, Y., Zhou, Y., Zhang, Y., Song, Z., Fan, J., Hu, B., and Liu, F. 2013a. AsnB, regulated by diffusible signal factor and global regulator $\mathrm{Clp}$, is involved in aspartate metabolism, resistance to oxidative stress and virulence in Xanthomonas oryzae pv. oryzicola. Mol. Plant Pathol. 14:145-157.

Qian, G., Zhou, Y., Zhao, Y., Song, Z., Wang, S., Fan, J., Hu, B., Venturi, V., and Liu, F. 2013b. Proteomic analysis reveals novel extracellular virulenceassociated proteins and functions regulated by the diffusible signal factor (DSF) in Xanthomonas oryzae pv. oryzicola. J. Proteome Res. 12:3327-3341.

Qian, W., Han, Z. J., Tao, J., and He, C. 2008. Genome-scale mutagenesis and phenotypic characterization of two-component signal transduction systems in Xanthomonas campestris pv. campestris ATCC 33913. Mol. Plant-Microbe Interact. 21:1128-1138.

Rashid, M. M., Ikawa, Y., and Tsuge, S. 2016. GamR, the LysR-type galactose metabolism regulator, regulates $h r p$ gene expression via transcriptional activation of two key hrp regulators, HrpG and HrpX, in Xanthomonas oryzae pv. oryzae. Appl. Environ. Microbiol. 82:3947-3958.

Rodriguez-R, L. M., Grajales, A., Arrieta-Ortiz, M. L., Salazar, C., Restrepo, S., and Bernal, A. 2012. Genomes-based phylogeny of the genus Xanthomonas. BMC Microbiol. 12:43.

Rodríguez-Sanz, M., Antunez-Lamas, M., Rojas, C., Lopez-Solanilla, E., Palacios, J. M., Rodriguez-Palenzuela, P., and Rey, L. 2010. The Tat pathway of plant pathogen Dickeya dadantii 3937 contributes to virulence and fitness. FEMS Microbiol. Lett. 302:151-158.

Rose, R. W., Bruser, T., Kissinger, J. C., and Pohlschroder, M. 2002. Adaptation of protein secretion to extremely high-salt conditions by extensive use of the twin-arginine translocation pathway. Mol. Microbiol. 45:943-950.

Rott, P. C., Fleites, L., Marlow, G., Royer, M., and Gabriel, D. W. 2009. An OmpA family outer membrane protein is required for both disease symptom development and sugarcane stalk colonization by Xanthomonas albilineans. (Abstr.) Phytopathology 99:S110.
Royer, M., Koebnik, R., Marguerettaz, M., Barbe, V., Robin, G. P., Brin, C., Carrere, S., Gomez, C., Hugelland, M., Voller, G. H., Noell, J., Pieretti, I., Rausch, S., Verdier, V., Poussier, S., Rott, P., Sussmuth, R. D., and Cociancich, S. 2013. Genome mining reveals the genus Xanthomonas to be a promising reservoir for new bioactive non-ribosomally synthesized peptides. BMC Genomics 14:658.

Salzberg, S. L., Sommer, D. D., Schatz, M. C., Phillippy, A. M., Rabinowicz, P. D., Tsuge, S., Furutani, A., Ochiai, H., Delcher, A. L., Kelley, D., Madupu, R., Puiu, D., Radune, D., Shumway, M., Trapnell, C., Aparna, G., Jha, G., Pandey, A., Patil, P. B., Ishihara, H., Meyer, D. F., Szurek, B., Verdier, V., Koebnik, R., Dow, J. M., Ryan, R. P., Hirata, H., Tsuyumu, S., Won Lee, S., Seo, Y. S., Sriariyanum, M., Ronald, P. C., Sonti, R. V., Van Sluys, M. A., Leach, J. E., White, F. F., and Bogdanove, A. J. 2008. Genome sequence and rapid evolution of the rice pathogen Xanthomonas oryzae pv. oryzae PXO99A. BMC Genomics 9:204.

Tamir-Ariel, D., Rosenberg, T., Navon, N., and Burdman, S. 2012. A secreted lipolytic enzyme from Xanthomonas campestris pv. vesicatoria is expressed in planta and contributes to its virulence. Mol. Plant Pathol. 13:556-567.

Tullman-Ercek, D., DeLisa, M. P., Kawarasaki, Y., Iranpour, P., Ribnicky, B., Palmer, T., and Georgiou, G. 2007. Export pathway selectivity of Escherichia coli twin arginine translocation signal peptides. J. Biol. Chem. 282: 8309-8316.

Vogel, A., Schilling, O., Niecke, M., Bettmer, J., and Meyer-Klaucke, W. 2002. ElaC encodes a novel binuclear zinc phosphodiesterase. J. Biol. Chem. 277:29078-29085.

Widdick, D. A., Dilks, K., Chandra, G., Bottrill, A., Naldrett, M., Pohlschroder, M., and Palmer, T. 2006. The twin-arginine translocation pathway is a major route of protein export in Streptomyces coelicolor. Proc. Natl. Acad. Sci. USA 103:17927-17932.

Yang, B., and Bogdanove, A. 2013. Inoculation and virulence assay for bacterial blight and bacterial leaf streak of rice. Pages 249-255 in: Rice Protocols. Methods in Molecular Biology, Vol. 956. Y. Yang, ed. Humana Press, New York.

Yu, C. S., Chen, Y. C., Lu, C. H., and Hwang, J. K. 2006. Prediction of protein subcellular localization. Proteins 64:643-651.

Yu, N. Y., Wagner, J. R., Laird, M. R., Melli, G., Rey, S., Lo, R., Dao, P., Sahinalp, S. C., Ester, M., Foster, L. J., and Brinkman, F. S. 2010. PSORTb 3.0: Improved protein subcellular localization prediction with refined localization subcategories and predictive capabilities for all prokaryotes. Bioinformatics 26:1608-1615.

Zhao, Y., Qian, G., Yin, F., Fan, J., Zhai, Z., Liu, C., Hu, B., and Liu, F. 2011. Proteomic analysis of the regulatory function of DSF-dependent quorum sensing in Xanthomonas oryzae pv. oryzicola. Microb. Pathog. 50:48-55.

Zheng, D., Yao, X., Duan, M., Luo, Y., Liu, B., Qi, P., Sun, M., and Ruan, L. 2016. Two overlapping two-component systems in Xanthomonas oryzae pv. oryzae contribute to full fitness in rice by regulating virulence factors expression. Sci. Rep. 6:22768. 